\title{
Development and sensory evaluation of ready to eat supplementary food using garden cress (Lepidium sativum) seeds
}

\author{
Tanu Jain $^{1 *}$, Kiran Grover ${ }^{1}$ and Inderjit Singh Grewal ${ }^{2}$ \\ ${ }^{1}$ Department of Food and Nutrition, Punjab Agricultural University, Ludhiana (Punjab), INDIA \\ ${ }^{2}$ Department of Maths, Statistics and Physics, Punjab Agricultural University, Ludhiana (Punjab), INDIA \\ *Correspondig author. E mail: jain.tanu25@gmail.com
}

Received: November 26, 2015; Revised received: May 17, 2016; Accepted: August 08, 2016

\begin{abstract}
Ready-to-eat traditional supplementary food was prepared using different substitution levels of garden cress seeds and evaluated using 9 point hedonic scale for sensory attributes. Addition of garden cress seeds showed significant difference at 15 and 10 per cent for Indian food pinni and panjiri and 5 per cent level for laddu and burfi for overall acceptability. For chikki, non significant difference was found in the mean scores for overall acceptability $(\mathrm{P}<0.05)$. In case of biscuits, values did not differ significantly at 7.5 per cent while significant difference was shown at 10 per cent. Supplementation of garden cress did not affect texture of foods except burfi where at 15 percent level significant difference was found. Overall acceptability of all developed products was found to be highest for control which decreased gradually with the increase in the level of garden cress powder. It may be concluded that garden cress can be utilized successfully up to 10-25 per cent level to prepare ready-to-eat supplementary food with high nutritional value without imposing a negative impact on sensory perception, which may prove a boon to malnourished population.
\end{abstract}

Keywords: Anaemia, Garden cress seeds, Malnutrition, Supplementary food

\section{INTRODUCTION}

Garden cress (Lepidium sativum, family- Cruciferae) (Dhiman, 2006) has been considered as an important nutritional and medicinal plant in India due to its health promoting properties (Mahassni and Al-Reemi, 2013; Mohite et al, 2012; Doke and Guha, 2014) and it's seeds constitute the most remarkable concentration of protein (22-26g/100g) (Gokavi et al., 2004; Gopalan et al., 2011; Al-Jasass and Al-Jasser, 2012; iron $(100 \mathrm{mg} / 100 \mathrm{~g})$ and other nutrients (thiamine, $0.59 \mathrm{mg} / 100 \mathrm{~g}$; riboflavin, $0.61 \mathrm{mg} / 100 \mathrm{~g}$; niacin, $14.3 \mathrm{mg} / 100 \mathrm{~g}$ ) (Gopalan et al., 2011) which can combat malnutrition, anemia and other micronutrient deficiencies. It provides good amount of calories $(454 \mathrm{kcal} / 100 \mathrm{~g})$ and fat $(24.5 \%)$. It acts as memory boosters as it contains essential fatty acids like arachidic and linoleic acid. It is a good source of calcium (377 mg/100g) and magnesium (430mg/100g) which helps in normal contraction of muscle for healthy movements of limbs and heart. It can be said like garden cress seeds are packed with power of nutrients. It is grown in all parts of India and known as "Common cress", "Land cress", "Haliv", "Asalio" or "Chandrasur" in India (Divanji et al., 2012; Kasabe et al., 2012; Rehman et al., 2011).

Malnutrition is the worst form of non-communicable disease and is an important risk factor for chronic diseases at a later date. Data from around the world show that the major cause of most nutritional problems is inadequate dietary intake (FAO, 2004). UNICEF reported (2013), in India, 48 percent under five years of age are stunted and the percentage of prevalence of wasting and underweight is 19.8 and 42.5 respectively. Supplementary food using garden cress seeds can be one of the best ways to improve the health and nutritional status. Since it is cost effective and easily accessible, so an attempt has been made to develop healthy ready-to-eat supplementary food using garden cress seeds to reduce malnutrition in community (Kaur, 2015). The present investigation was carried out to study the development and sensory evaluation of ready to eat supplementary food using garden cress (Lepidium sativum) seeds.

\section{MATERIALS AND METHODS}

Procurement of garden cress seeds: Garden cress seeds, used for the preparation of food products, were purchased from local market. The seeds were roasted (at $150^{\circ} \mathrm{C}$ for $3-5$ minutes) in an iron vessel on a low flame till a prominent aroma of garden cress seeds comes. After cooling, the seeds were ground in grinder. The roasted seed powder was packed in air tight plastic container.

Chemical analysis: Proximate composition viz. crude protein, crude fat, minerals, crude fiber was analyzed by standard methods (AOAC, 2000). For total minerals, the samples were wet digested in hot plate using ISSN : 0974-9411 (Print), 2231-5209 (Online) All Rights Reserved @ Applied and Natural Science Foundation www.jans.ansfoundation.org 
nitric acid and perchloric acid mixture in 5:1 ratio (v/v) and used for the determination of total amount of calcium, iron and zinc by atomic absorption spectrophotometry (Lindsey and Norwell, 1969).

Development of supplementary Indian food: Supplementary food were developed by incorporating roasted garden cress seeds in primary ingredient at 5 , 10 and $15 \%$ level for pinni, panjiri, laddu and burfi, 15, 20, 25 per cent for Chikki and 5, 7.5 and 10 percent for biscuits in the Food Laboratory of Food and Nutrition Department, College of Home Science, PAU, Ludhiana.

Pinni : Overnight soaked and ground green gram (60g, raw weight) was deep fried in ghee $(50 \mathrm{~g})$ till it turns golden brown and ground again after cooling. Wheat flour $(60 \mathrm{~g})$ was roasted in ghee $(10 \mathrm{~g})$ for 8-10 minutes on low flame and mixed all ingredients with jaggery (75g) on cooling. The mixture was divided into 5 equal portions by weight and turned it into small balls with the help of palm (Nagi and Mann, 2003).

Panjiri : Wheat flour $(100 \mathrm{~g})$ was roasted with ghee $(50 \mathrm{~g})$ on a slow fire for 10 minutes and after cooling the mixture, powdered jaggery $(100 \mathrm{~g})$ was added thoroughly (Kaur, 2013).

Laddu: Mix (whole wheat flour:bengal gram flour :: $1: 3)$ flour $(100 \mathrm{~g})$ was roasted with ghee $(50 \mathrm{~g})$ on a low flame for 10 minutes and ground sugar $(100 \mathrm{~g})$ was added after cooling it at room temperature. The mixture was divided into 5 equal portions by weight and turned it into small balls with the help of palm (Pant, 2011).

Burfi : Bengal gram flour (100g) was roasted with ghee $(100 \mathrm{~g})$ on a slow flame till it turns golden brown and 2 -string sugar syrup (80g sugar in $80 \mathrm{ml}$ water) was poured into mixture with continuous stirring. While hot, the mixture was spread evenly in an aluminium tray and cut into square shape with the help of sharp edged knife (Bansal, 2013).

For sugar syrup: Sugar $(80 \mathrm{~g})$ and water 1:1 ratio (w/v) was boiled together in a pan until sugar dissolves. A drop of Syrup was picked between the tip of index finger and thumb and pull apart slowly to see required strings. The syrup was boiled till it achieved 2 strings.

Chikki : Jaggery ( $80 \mathrm{~g}$ ) was crushed and made into syrup with addition of water $(40 \mathrm{ml})$ by heating it till the temperature reached $145^{\circ} \mathrm{C}$ and immediately roasted peanut halves was added after turning off the flame and mixed thoroughly till peanuts get coated with jaggery syrup. The mixture was poured on a pre greased surface and spread uniformly with the help of roller, cut into square pieces and kept for cooling at room temperature (Chetana and Sukireddy, 2011).

Biscuits : Wheat flour (250 g) was sieved with one fourth teaspoon sodium-bi-carbonate for even distribution and $125 \mathrm{~g}$ of sugar was added. Butter $(125 \mathrm{~g})$ was cut with the knife into small pieces and rubbed into the flour mixture with the help of wooden spoon until it is properly mixed. Milk (10 ml) was added, followed by sprinkling of deionised water and mixed until a ball of dough formed. The dough was rolled on a rolling board with a rolling pin to one fourth inch thickness. Flat dough was cut into round shapes using biscuit cutter ( $4 \mathrm{~cm}$ in diameter). The biscuits were baked on the pre-greased aluminium baking trays in a gas oven at $280^{\circ} \mathrm{C}$ for fifteen minutes. Biscuits were removed and cooled on a rack for five to seven minutes before sensory evaluation (Kulshreshta, 2008).

Sensory evaluation : All the supplementary food was processed for sensory evaluation immediately after development. The organoleptic characteristics of products were determined using a taste panel consisting of 10 judges who were familiar with the major sensory attributes of food products. The panellists were asked to evaluate the products for appearance, colour, texture, flavour and overall acceptability. Each day, four samples having one control and three experimental were presented in identical containers coded with different numbers and served simultaneously. Each sample was repeated thrice during the course of evaluation. The ratings were done on 9 point hedonic scale (Watts et al., 1989). The degree, to which a product was liked, was expressed as like extremely ( 9 point), like very much, ( 8 points), like moderately ( 7 points), like slightly (6 points), neither like nor dislike ( 5 points), dislike slightly (4 points), dislike moderately (3 points), dislike very much (2 points) and dislike extremely (1 point). The testing was conducted in food laboratory of the department of Food and Nutrition, College of Home Science, Punjab Agricultural University, Ludhiana.

Statistical analysis : The data were subjected to statistical analysis using Statistical Package for Social Sciences (SPSS) version 16.0. Tukey test was used to obtain the differences in organoleptic scores within control and different level of substitution of garden cress seeds in food preparation. Level of significance was accepted at 5 per cent $(\mathrm{p}<0.05)$.

\section{RESULTS AND DISCUSSION}

Chemical composition of roasted garden seed powder : Chemical composition of garden cress seeds is shown in table 1 which clearly stated that roasted gar-

Table1. Chemical composition of roasted garden cress powder (per $100 \mathrm{~g}, \mathrm{DM})$

\begin{tabular}{ll}
\hline Crude Protein $(\mathrm{g})$ & $23.29 \pm 0.03$ \\
Crude Fat $(\mathrm{g})$ & $22.72 \pm 0.006$ \\
Minerals $(\mathrm{g})$ & $5.12 \pm 0.02$ \\
Carbohydrate* $(\mathrm{g})$ & $38.76 \pm 0.07$ \\
Total Iron $(\mathrm{mg})$ & $28.68 \pm 0.16$ \\
Total Calcium $(\mathrm{mg})$ & $358.03 \pm 0.03$ \\
Total Zinc $(\mathrm{mg})$ & $4.18 \pm 0.06$ \\
Energy\# $(\mathrm{kcal})$ & $452.71 \pm 0.20$ \\
\hline
\end{tabular}

* Carbohydrate $=100-($ Minerals + Protein+Fat+Fibre $)$; Energy $=($ Protein $\times 4)+($ Carbohydrate $\times 4)+($ Fat $\times 9) ;$ Values are mean $\pm \mathrm{SD}$; Values are taken in triplicate 
Tanu Jain et al. / J. Appl. \& Nat. Sci. 8 (3): 1501 - 1506 (2016)

Table 2. Sensory evaluation of supplementary Indian food using garden cress seeds

\begin{tabular}{|c|c|c|c|c|c|}
\hline \multirow[b]{2}{*}{ Supplementary Food } & \multicolumn{5}{|c|}{ Sensory attributes } \\
\hline & Appearance & Colour & Texture & $\begin{array}{l}\text { Flavour } \\
\text { (taste and } \\
\text { aroma) }\end{array}$ & $\begin{array}{l}\text { Overall accept- } \\
\text { ability }\end{array}$ \\
\hline \multicolumn{6}{|l|}{ Pinni } \\
\hline Control & $7.9^{\mathrm{a}} \pm 0.57$ & $7.7^{\mathrm{a}} \pm 0.82$ & $7.7^{\mathrm{a}} \pm 0.82$ & $8.0^{\mathrm{a}} \pm 0.67$ & $7.83^{\mathrm{a}} \pm 0.67$ \\
\hline $5 \%$ & $7.2^{\mathrm{ab}} \pm 0.63$ & $7.0^{\mathrm{ab}} \pm 0.82$ & $7.8^{\mathrm{a}} \pm 0.63$ & $7.4^{\mathrm{ab}} \pm 0.52$ & $7.35^{\mathrm{ab}} \pm 0.56$ \\
\hline $10 \%$ & $7.3^{\mathrm{ab}} \pm 0.48$ & $7.4^{\mathrm{ab}} \pm 0.52$ & $7.6^{\mathrm{a}} \pm 0.52$ & $7.3^{\mathrm{b}} \pm 0.48$ & $7.4^{\mathrm{ab}} \pm 0.38$ \\
\hline $15 \%$ & $6.9^{b} \pm 0.74$ & $6.6^{\mathrm{b}} \pm 0.70$ & $7.5^{\mathrm{a}} \pm 0.53$ & $6.5^{c} \pm 0.53$ & $7.36^{\mathrm{b}} \pm 0.61$ \\
\hline \multicolumn{6}{|l|}{ Panjiri } \\
\hline Control & $8.1^{\mathrm{a}} \pm 0.32$ & $8.1^{\mathrm{a}} \pm 0.57$ & $7.9^{\mathrm{a}} \pm 0.32$ & $8.4^{\mathrm{a}} \pm 0.52$ & $8.13^{\mathrm{a}} \pm 0.29$ \\
\hline $5 \%$ & $7.5^{\mathrm{ab}} \pm 0.53$ & $7.4^{\mathrm{ab}} \pm 0.69$ & $7.6^{\mathrm{a}} \pm 0.52$ & $7.5^{\mathrm{b}} \pm 0.52$ & $7.50^{\mathrm{bc}} \pm 0.42$ \\
\hline $10 \%$ & $7.7^{\mathrm{ab}} \pm 0.48$ & $7.8^{\mathrm{ab}} \pm 0.63$ & $7.7^{\mathrm{a}} \pm 0.48$ & $7.6^{\mathrm{bc}} \pm 0.53$ & $7.70^{\mathrm{ab}} \pm 0.39$ \\
\hline $15 \%$ & $7.2^{b} \pm 0.63$ & $7.3^{\mathrm{b}} \pm 0.48$ & $7.4^{a} \pm 0.52$ & $6.9^{c} \pm 0.57$ & $7.2^{c} \pm 0.39$ \\
\hline \multicolumn{6}{|l|}{ Laddu } \\
\hline Control & $8.3^{\mathrm{a}} \pm 0.48$ & $8.1^{\mathrm{a}} \pm 0.74$ & $7.9^{\mathrm{a}} \pm 0.74$ & $8.0^{\mathrm{a}} \pm 0.67$ & $8.06^{\mathrm{a}} \pm 0.55$ \\
\hline $5 \%$ & $7.3^{\mathrm{bc}} \pm 0.48$ & $7.2^{\mathrm{b}} \pm 0.63$ & $7.5^{\mathrm{a}} \pm 0.53$ & $7.4^{\mathrm{ab}} \pm 0.53$ & $7.35^{\mathrm{bc}} \pm 0.24$ \\
\hline $10 \%$ & $7.8^{\mathrm{ab}} \pm 0.42$ & $7.5^{\mathrm{ab}} \pm 0.53$ & $7.6^{\mathrm{a}} \pm 0.70$ & $7.5^{\mathrm{a}} \pm 0.52$ & $7.6^{b} \pm 0.39$ \\
\hline $15 \%$ & $6.8^{\mathrm{c}} \pm 0.63$ & $6.9^{b} \pm 0.57$ & $7.4^{\mathrm{a}} \pm 0.52$ & $6.8^{\mathrm{b}} \pm 0.42$ & $6.98^{\mathrm{c}} \pm 0.28$ \\
\hline \multicolumn{6}{|l|}{ Burfi } \\
\hline Control & $8.2^{\mathrm{a}} \pm 0.63$ & $8.3^{\mathrm{a}} \pm 0.68$ & $8.2^{\mathrm{a}} \pm 0.79$ & $8.2^{\mathrm{a}} \pm 0.63$ & $8.23^{\mathrm{a}} \pm 0.59$ \\
\hline $5 \%$ & $7.4^{b} \pm 0.52$ & $7.3^{b} \pm 0.67$ & $7.7^{\mathrm{a}} \pm 0.48$ & $7.4^{b} \pm 0.53$ & $7.45^{\mathrm{b}} \pm 0.38$ \\
\hline $10 \%$ & $7.7^{\mathrm{ab}} \pm 0.48$ & $7.5^{\mathrm{b}} \pm 0.53$ & $8.0^{\mathrm{a}} \pm 0.67$ & $7.5^{b} \pm 0.52$ & $7.68^{\mathrm{b}} \pm 0.34$ \\
\hline $15 \%$ & $6.5^{c} \pm 0.53$ & $6.5^{c} \pm 0.53$ & $6.8^{\mathrm{b}} \pm 0.63$ & $6.3^{c} \pm 0.48$ & $6.53^{c} \pm 0.42$ \\
\hline \multicolumn{6}{|l|}{ Chikki } \\
\hline Control & $8.0^{\mathrm{a}} \pm 0.47$ & $8.1^{\mathrm{a}} \pm 0.57$ & $7.7^{\mathrm{a}} \pm 0.82$ & $7.4^{b} \pm 0.70$ & $7.8^{\mathrm{a}} \pm 0.50$ \\
\hline $15 \%$ & $7.5^{\mathrm{ab}} \pm 0.71$ & $7.5^{\mathrm{a}} \pm 0.53$ & $8.0^{\mathrm{a}} \pm 0.67$ & $7.7^{\mathrm{b}} \pm 0.48$ & $7.68^{\mathrm{a}} \pm 0.49$ \\
\hline $20 \%$ & $7.3^{b} \pm 0.48$ & $7.5^{\mathrm{a}} \pm 0.53$ & $8.0^{\mathrm{a}} \pm 0.67$ & $7.8^{\mathrm{ab}} \pm 0.42$ & $7.65^{\mathrm{a}} \pm 0.41$ \\
\hline $25 \%$ & $7.0^{b} \pm 0.67$ & $7.4^{\mathrm{a}} \pm 0.70$ & $8.1^{\mathrm{a}} \pm 0.88$ & $8.4^{\mathrm{a}} \pm 0.70$ & $7.73^{a} \pm 0.59$ \\
\hline \multicolumn{6}{|l|}{ Biscuits } \\
\hline Control & $7.9^{\mathrm{a}} \pm 0.88$ & $8.2^{\mathrm{a}} \pm 0.63$ & $7.9^{\mathrm{a}} \pm 0.74$ & $7.6^{\mathrm{a}} \pm 0.52$ & $7.9^{\mathrm{a}} \pm 0.44$ \\
\hline $5 \%$ & $8.1^{\mathrm{a}} \pm 0.57$ & $7.9^{\mathrm{ab}} \pm 0.32$ & $7.8^{\mathrm{a}} \pm 0.42$ & $7.5^{\mathrm{a}} \pm 0.52$ & $7.83^{\mathrm{a}} \pm 0.27$ \\
\hline $7.5 \%$ & $8.2^{\mathrm{a}} \pm 0.42$ & $8.0^{\mathrm{a}} \pm 0.47$ & $7.9^{\mathrm{a}} \pm 0.57$ & $7.6^{\mathrm{a}} \pm 0.53$ & $7.93^{\mathrm{a}} \pm 0.32$ \\
\hline $10 \%$ & $7.6^{\mathrm{a}} \pm 0.70$ & $7.3^{b} \pm 0.82$ & $7.5^{\mathrm{a}} \pm 0.53$ & $6.9^{\mathrm{a}} \pm 0.74$ & $7.33^{\mathrm{b}} \pm 0.47$ \\
\hline
\end{tabular}

Values are mean \pm SD; Values are taken in triplicate; Alphabets with different superscripts shows significant difference at $5 \%$ level of significance; Scores are out of nine on 9 point hedonic scale (9- Excellent, 8- Extremely good, 7- Very good, 6- Moderately good, 5- Good, 4- Fair, 3-Very fair, 2- Poor, 1- Very poor)

Table 3. Calculated nutritive value of developed acceptable Indian food products (per 100 grams, raw basis)

\begin{tabular}{lllllll}
\hline Parameter & Pinni & Panjiri & Laddu & Burfi & Chikki & Biscuits \\
\hline Energy (Kcal) & 488.75 & 474.04 & 483.46 & 569.89 & 470.7 & 456.44 \\
Protein (g) & 8.56 & 5.46 & 6.55 & 8.06 & 14.14 & 6.46 \\
Fat (g) & 25.23 & 21.56 & 21.93 & 38.19 & 19.73 & 21.88 \\
Carbohydrate (g) & 56.74 & 64.30 & 64.94 & 48.46 & 58.68 & 58.4 \\
Iron (mg) & 4.06 & 4.97 & 3.46 & 4.08 & 6.43 & 3.33 \\
Calcium (mg) & 63.25 & 64.30 & 37.60 & 34.57 & 117.27 & 36.08 \\
Zinc (mg) & 1.28 & 1.2 & 1.43 & 2.11 & 2.21 & 1.18 \\
\hline
\end{tabular}

Acceptable level: Pinni, Panjiri, Laddu and Burfi at 10\%, Chikki at $25 \%$ and Biscuits at $7.5 \%$

den seed was found to be rich in protein $(23.29 \pm$ $0.025)$ and fat (22.72 \pm .0052$)$. Gaafar et al. (2013) found $24.29 \mathrm{~g}$ protein and $27.85 \mathrm{~g}$ of lipid in whole garden cress seeds. The seeds contained good amount of iron $(28.68 \pm 0.16)$ and zinc $(4.18 \pm 0.06)$. Total amount of calories $(452.71 \pm 0.20)$ was found to be higher than that of cereals and pulses. So, the seeds, being rich in protein, fat and minerals, may provide a good option to be supplemented in foods.

Sensory evaluation : Sensory evaluation of different supplementary foods developed using garden cress seed is shown in the Table 2 and Fig. 1.

Pinni : The results stated that the control sample of pinni was given scores ranging from 7.7 to 8.0 for dif- 


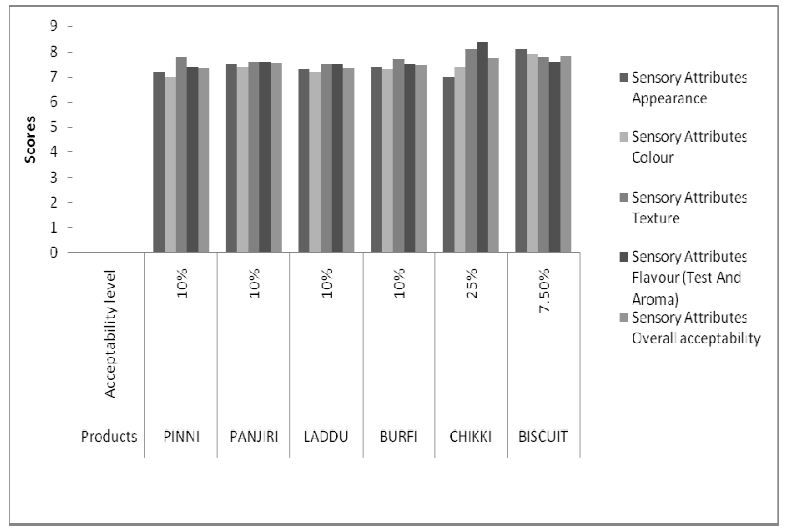

Fig. 1. Scoring of acceptable garden cress supplemented Indian food products on 9 point hedonic scale.

ferent quality attributes which were highest among all test samples. In case of appearance and color, significant $(\mathrm{p} \leq 0.05)$ scores were gained by control $(7.9 \pm$ 0.57 and $7.7 \pm 0.82)$ and least scores $(6.9 \pm 0.74$ and $6.6 \pm 0.70)$ were given to 15 per cent level. Supplementation of roasted garden cress powder did not affect the texture $(\mathrm{p} \leq 0.05)$ but impaired the flavour of pinni possibly due to tangy taste of seeds which decreased the scores significantly $(\mathrm{p} \leq 0.05)$ from control $(8.0 \pm 0.67)$ to 15 per cent level $(6.5 \pm 0.53)$. Addition of roasted garden cress seed powder was equally acceptable 5 and 10 per cent level for all parameters while 15 per cent level of supplementation was found to be least acceptable. A non significant difference ( $\mathrm{p} \leq$ $0.05)$ was found among overall acceptability scores of control $(7.83 \pm 0.67), 5(7.4 \pm 0.38)$ and 10 per cent $(7.35 \pm 0.56)$ level which maximized the probability of supplementation of garden cress powder without imposing a negative impact on sensory perception.

Panjiri : The perusal of the data (Table 2) showed that best score was obtained by control for all organoleptic attributes. The reason may be the developed taste and appearance of traditional panjiri. In case of appearance and colour, the scores of 5 and 10 per cent supplementation showed non significant difference but 15 per cent was found significantly different from all treatments and obtained the least scores. Texture of panjiri was not altered by supplementation of garden cress powder in all treatments. In case of flavour, 10 per cent level of garden cress supplementation achieved highest $(7.6 \pm 0.53)$ scores among all treatments after control $(8.4 \pm 0.52)$ and found significantly different $(\mathrm{p} \leq$ $0.05)$. A level of 15 per cent $(6.9 \pm 0.57)$ was least liked by the judges. All treatments were found statistically significant from control for this parameter. Among all treatments, overall acceptability was found highest for 10 per cent level with $7.70 \pm 0.39$ scores, followed by 5 and 15 per cent with $7.50 \pm 0.42$ and 7.2 \pm 0.39 scores. The difference between the scores of 10 per cent and control was found to be non significant.
Similar result was found for panjiri supplemented with partially defatted peanut flour which improved all organoleptic parameters with overall acceptability scores of 8.04 with non significant difference among treatments and control (Bansal, 2013). Potato flour substituted panjiri was liked very much and showed non-significant difference as compared with control (Kaur, 2013).

Laddu : The mixed results were obtained in case of laddu (Table 2). A decrease trend was observed in scores of appearance, color and texture in laddu with the increase in garden cress powder. The control laddu was more liked by the panelists than that of treatments. Scores for appearance and colour of the laddu decreased from extremely liked (for control) to very good (for 5 and $10 \%$ ). The levels of supplementation at 5 and 10 per cent was found to be non significant while 15 per cent level were found significantly different from control. Scores for texture, decreased from control to 15 per cent level of supplementation but non significant results was computed between the scores. In case of flavour, 5 and 10 per cent garden cress level slightly differed in their mean scores $(7.4 \pm 0.53 \mathrm{vs} .7 .5$ \pm 0.52 ) and found to be non-significant. Control achieved the highest scores $(8.06 \pm 0.55)$ while 15 per cent level was given the least scores $(6.98 \pm 0.28)$ with significant difference with control and 10 per cent. The mean scores for overall acceptability was found to be highest $(8.06 \pm 0.55)$ for control followed by $10(7.6 \pm$ $0.39)$ and $5(7.35 \pm 0.24)$ per cent level with significant difference. A level of 15 per cent supplementation was given least scores $(6.98 \pm 0.28)$. Addition of sesame seeds improved the color, texture and taste and thus overall acceptability of laddu (Verma et al., 2014) and laddu prepared from soy blends were found to be equally acceptable when compared with control (Singh and Singh, 2009).

Burfi : The scores of organoleptic attributes significantly decreased with increase in garden cress supplementation (Table 2). In case of appearance, control was given $8.2 \pm 0.63$ scores, followed by $7.7 \pm 0.48$ scores for 10 per cent and $7.4 \pm 0.52$ for 5 per cent level of supplementation. A level of 15 per cent supplementation received minimum scores with 6.5. Ten per cent level of supplementation was found to be non significant and 5 and 15 per cent were found significantly different as compared to control. Similar result was found in case of colour where, scores decreased from $8.3 \pm 0.68$ (control) to $6.5 \pm 0.53(15 \%)$. Garden cress seeds supplementation up to 10 per cent did not affect the texture of burfi but high amount of fat in 15 per cent level was found to be responsible for the loose binding of particles of burfi and sugar. Texture of control was liked most $(8.2 \pm 0.79)$ by the judges followed by 10,5 and 15 per cent. The results showed a non significant difference $(p \leq 0.05)$ in case of texture among all treatments and control. In case of flavour, non significant difference was found in scores of 5 (7.4 
$\pm 0.53)$ and $10(7.5 \pm 0.52)$ per cent level but significant difference was observed with control which attained highest scores with $8.2 \pm 0.63$. Burfi prepared by using 15 per cent level of garden cress supplementation was liked least by the panelists. Overall highest scores $(8.23 \pm 0.59)$ were obtained by control and least scores $(6.53 \pm 0.42)$ by 15 per cent level of garden cress seed powder supplementation with a significant difference $(\mathrm{p} \leq 0.05)$. After control, $10(7.68 \pm 0.34)$ and 5 per cent $(7.45 \pm 0.38)$ level of supplementation were liked more as compared to 15 per cent and found significantly different from control as well as 15 per cent level of garden cress supplementation. A study of Bansal (2013) supported the results and showed that overall acceptability of burfi supplemented with partially defatted peanut flour with non significant difference as compared with control. Kaur (2013) also reported the non significant difference between control and potato flour incorporated burfi.

Chikki : The scores of chikki revealed (Table 2) that control was scored as extremely good but scores decreased sharply till 25 per cent level of supplementation in case of appearance and color attributes. In case of appearance, 15 per cent level of garden cress supplementation scored highest $(7.5 \pm 0.71)$ scores, followed by $20(7.3 \pm 0.48)$ and 25 per cent $(7.0 \pm 0.67)$ levels. The difference among all the treatments was found to be significant except 15 per cent level of supplementation. In case of colour, control was awarded as 'extremely good' while all treatments were considered as 'very good' on rating scale. It may be due to dark brown color of seeds which made appearance of chikki little dull. Crunchiness of seeds, which improved texture of chikki was responsible for the highest scores $(8.1 \pm 0.88)$, achieved by 25 per cent level of substitution of garden cress, followed by 15 and 20 per cent with same scores of 8.0. The control was given the minimum mean scores $(7.7 \pm 0.82)$ with non significant difference as compared to all treatments. Similar results were found in case of flavour, in which, highest scores was achieved by 25 per cent level ( $8.4 \pm$ $0.70)$ with significant difference $(\mathrm{p} \leq 0.05)$ which may be due to aroma and taste of seeds. The scores gradually decreased till 15 per cent $(7.7 \pm 0.48)$. The particular aroma of oilseeds may be because of Maillard reaction, lipid and protein oxidation and degradation or caramelisation during roasting (Durmaz and Gökmen, 2010). The least scores were obtained by control (7.4 \pm $0.70)$. Overall, 25 per cent supplementation of garden cress seeds for peanuts among all treatments was liked very much $(7.73 \pm 0.59)$, but control chikki was awarded with slightly higher scores $(7.8 \pm 0.50)$ due to developed sense of traditional chikki. A non significant difference was found between any treatment and control. From overall acceptability ratings, it may be concluded that whole roasted garden cress seeds can be supplemented in chikki up to 25 per cent level, without affecting its sensory qualities. Peanut chikki developed by incorporating soy protein isolate showed similarity with control in all organoleptic attributes except colour (Byrappa et al., 2014).

Biscuits- On perusal of the data (Table 2), it was found that supplementation of garden cress seed powder at 5 and 7.5 per cent improved the appearance of biscuits due to clear visibility of evenly spread brown coloured garden cress particles $(8.1 \pm 0.57$ and $8.2 \pm 0.42)$. But at 10 per cent level, it decreased $(7.6 \pm 0.70)$. No treatment was found significantly different, when compared with control which was given $7.9 \pm 0.88$ scores. In case of colour, control got highest scores (8.2 \pm $0.63)$ followed by $7.5(8.0 \pm 0.47), 5(7.9 \pm 0.32)$ and 10 per cent $(7.3 \pm 0.82)$ and only 10 per cent level was found statistically significant $(\mathrm{p} \leq 0.05)$ with control. A non significant difference was found in the mean scores of control and all treatments for texture, ranged from 7.9 (control and $7.5 \%$ ) to $7.5(10 \%)$. For flavour, highest scores $(7.6 \pm 0.53)$ was attained by control and 7.5 per cent level of garden cress seed powder supplementation, followed by 5 per cent $(7.5 \pm 0.52)$ with non significant difference. The least scores $(6.9 \pm$ 0.74) were computed for 10 per cent level of supplementation in case of flavour. Overall 10 per cent level of garden cress seeds supplementation differed significantly $(\mathrm{p} \leq 0.05)$ from other treatments and control and got the least scores $(7.33 \pm 0.47)$. Ratings of overall acceptability encouraged the addition of garden cress powder at 7.5 per cent level which got highest scores of $7.93 \pm 0.32$, followed by 5 per cent $(7.83 \pm 0.27)$. No difference was found in all parameters in the cereal based nutricookies incorporating garden cress seeds except texture which was found little hard in sample containing highest amount of seeds (Nathiya and Vigasini, 2014). Similar findings were repeated in case of appearance of biscuits incorporated with amla powder which improved appearance, texture, flavour and overall acceptability of biscuits (Kulshreshta, 2008). Non significant result was found for all sensory parameters when biscuits were prepared using potato flour (Kaur 2013).

Data from the Table 3 showed that highest energy content was found in burfi $(569.89 \mathrm{kcal} / 100 \mathrm{~g})$, followed by pinni (488.75 kcal/100g) and laddu (483.46 $\mathrm{kcal} / 100 \mathrm{~g}$ ). This might due to high fat content of products. Chikki was found to be richest in protein with $8.56 \mathrm{~g} / 100 \mathrm{~g}$ among all products, followed by pinni $(8.56 \mathrm{~g} / 100 \mathrm{~g})$. Calculated iron and calcium was found to be highest in chikki $(6.43 \mathrm{mg} / 100 \mathrm{~g}$ iron and 117.27 $\mathrm{mg} / 100 \mathrm{~g}$ calcium), followed by panjiri $(4.97 \mathrm{mg} / 100 \mathrm{~g}$ iron and $64.30 \mathrm{mg} / 100 \mathrm{~g}$ calcium). Overall nutritive value of all supplementary foods was found to be high with good amount of micronutrients.

\section{Conclusion}

With increase in the level of garden cress powder in all preparations, the overall acceptability decreased. Sub- 
stitution of garden cress seed powder at least up to 10 percent level can be made for most of the supplementary food except chikki (25\%) and biscuits (7.5\%). On the basis of the findings, it may be concluded that ready-to-eat supplementary Indian food can be successfully prepared using garden cress seed powder with high nutritional value without imposing a negative impact on sensory attributes, which can prove a boon to malnourished population.

\section{REFERENCES}

Al-Jasass, F.M. and Al-Jasser, M.S. (2012). Chemical composition and fatty acid content of some spices and herbs under Saudi Arebia conditions. The Scientific World Journal. doi: $10.1100 / 2012 / 859892$

AOAC, (2000). Official methods of analysis, $13^{\text {th }}$ edition, Association of Official Analytical Chemists. Washington DC.

Bansal, P. (2013). Development of value added products using peanut flour for nutritional and health benefits. M.Sc. Thesis, Punjab Agricultural University, Ludhiana, India.

Byrappa, V.P., Ramakrishna, C. and Sunkireddy, Y.R. (2014). Processing, physic-chemical, sensory and nutritional evaluation of protein, mineral and vitamin enriched peanut chikki - an Indian traditional sweet. J. Food Sci. Technol. 51(1): 158-162.

Chetana, R. and Sukireddy, Y.R. (2011). Preparation and quality evaluation of peanut chikki incorporated flax seeds. $J$. Food Sci. Technol. 48(6): 745-749.

Dhiman, A.K. (2006). Ayurvedic drug plants. Daya Publishing House, Delhi, pp 97-99.

Divanji, M., Viswanatha, G.L., Nagesh, S., Jain, V. and Shivaprasad, H.N. (2012). Ethnopharmacology of Lepidium sativum Linn (Brassicaceae): a review. Int. J. Phytother. Res. 2:1-7.

Doke, S. and Guha, M. (2014). Garden cress (Lepidium sativum L.) seed- an important medicinal source: a review J. Nat. Prod. Plant Resour. 4(1): 69-80.

Durmaz, G. and Gökmen, V. (2010). Impacts of roasting oily seeds and nuts on their extracted oils. Lipid Technol. 22: 179-182.

Food and Agriculture Organization of the United Nations (2004). Undernourishment around the world: The state of food insecurity in the world, Rome.

Gaafar, A.M., Morsi, A.A. and Elghamry, H.E. (2013). Chemical, nutritional and biochemical studies of garden cress protein isolate. Nat. Sci. 11(2): 8-13.

Gokavi, S.S., Malleshi, N.G. and Guo, M. (2004). Chemical composition of garden cress (Lepidium sativum) seeds and its fractions and use of bran as a functional ingredient. Plant Foods Hum. Nutr. 59: 105-111.

Gopalan, C., Sastri, B.V.R., Balasubramanian, S.C., Rao, B.S.N., Deosthale, Y.G. and Pant, K.C. (2011). Nutritive
Value of Indian Foods. National Institute of Nutrition, Indian Council of Medical Research, Hyderabad, India.

Kasabe, P.J., Patil, P.N., Kamble, D.D. and Dandge, P.B. (2012). Nutritional, elemental analysis and antioxidant activity of garden cress (Lepidium sativum L.) seeds. Int. J. Pharm. Pharm. Sci. 4(3): 392-395.

Kaur, A. (2013). Development of value added products using potato flour for nutritional and health benefits. M.Sc. Thesis, Punjab Agricultural University, Ludhiana, India.

Kaur J (2015) Food based strategies to combat protein energy malnutrition among school children. MSc thesis, Punjab Agricultural University, Ludhiana, India.

Kulshreshta, K. (2008). Development of value added amla (Phyllanthus emblica) based baked products and evaluation of their antioxidant activity. M.Sc. Thesis, Punjab Agricultural University, Ludhiana, India.

Lindsey, W.L and Norwell, M.A. (1969). A new DPTA- TEA soil test for zinc and iron. Agron. Absts. 6: 84.

Mahassni, S.H. and Al-Reemi, R.M. (2013). Apoptosis and necrosis of human breast cancer cells by an aqueous extract of garden cress (Lepidium sativum) seeds. Saudi J. Biol. Sci. 20:131-139.

Mohite, S.Y., Gharal, D.B., Ranveer, R.C., Sahoo, A.K. and Ghosh, J.S. (2012). Development of health drinks enriched with processed garden cress (Lepidium sativum L.) seeds. Am. J. Food Technol. 7: 571-576.

Nagi, M.K. and Mann, S.K. (2003). Traditional Punjabi Recipes. Centre for communication, languages and culture. Punjab Agricultural University, Ludhiana.

Nathiya, M. and Vigasini, N. (2014). Formulations of cereal based nutricookies prepared incorporating garden cress seeds (Lepidium sativum) - a protein and iron rich snack. Int. J. Sci. Res. 3(2): 225-226.

Pant, R. (2011). Development and nutritional evaluation of value added cereal pulse based products using drumstick leaves (Moringa oleifera). M.Sc. Thesis, Punjab Agricultural University, Ludhiana, India.

Rehman, N., Mehmood, M.H., Alkharfy, K.M. and Gilani, A.H. (2011). Prokinetic and laxative activities of Lepidium sativum seed extract with species and tissue selective gut stimulatory actions J. Ethnopharmacol. 134: 878-883.

Singh, G. and Singh, P. (2009). Preparation of soy blended product and their organoleptic evaluation. Shodh, sameeksha aur moolyankan 2(6): 808-810.

UNICEF (2013). Improving child nutrition: The achievable imperative for global progress, New York, pp 9-12.

Verma, A., Bala, N., Shukla, M. and Sheikh, S. (2014). Preparation of low cost snack by incorporation of developed flour mixtures. Int. Res. J. Pharm. App. Sci. 4(1): 61-63.

Watts, B.M., Ylimaki, G.L., Jeffery, L.E. and Elias, L.G. (1989). Basic sensory methods for food evaluation.IDRC277e. The International Development research Centre, Ottawa, Canada. 